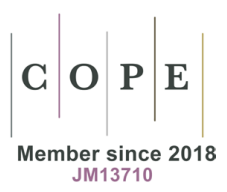

EUROPEAN SPATIAL RESEARCH AND POLICY

\begin{tabular}{lrr} 
Volume 27 & 2020 & Number 1 \\
\hline
\end{tabular}

http://dx.doi.org/10.18778/1231-1952.27.1.11

\author{
Mohammad HASANI* (D), Abdolrassoul SALMANMAHINY* (D), \\ Alireza Mikaeili TABRIZI*
}

\title{
AN INTEGRATIVE MODELLING APPROACH TO ANALYSE LANDSCAPE DYNAMICS THROUGH INTENSITY ANALYSIS AND CELLULAR AUTOMATA-MARKOV CHAIN MODEL
}

\begin{abstract}
The goal of this study is offer a deep understanding of the landscape dynamics in the Gorgan Township, the Golestan Province, Iran. Landsat satellite imagery of two different time thresholds, i.e. the years 1992 and 2011, was acquired from the US Geological Survey database and the changes were quantified for the Gorgan area covering a 19-year time span. Furthermore, an integrated Cellular Automata-Markov Chain (CA-MC) model was applied to predict future changes up to the year 2030. We used the intensity analysis method to compare the historical dynamics of different land categories at multiple levels. The results indicated that during the 19 years, the built-up and forest areas increased by $2.33 \%$ and $0.27 \%$, respectively, while agriculture and remnant vegetation decreased by $2.43 \%$ and $0.24 \%$, respectively. The CA-MC model illustrated that in the following 19 years, the built-up areas could increase by $2.45 \%$. An intensity analysis revealed that forest gains and losses were dormant while remnant vegetation gains and losses were active. The built-up area's gains and water bodies' losses were active and stationary during both time intervals. The transitions from water bodies and remnant vegetation to agriculture were regularly targeting and stationary, while the transition from forest to agriculture was regularly avoiding and stationary. Our findings also indicated a heavy systematic transition from agriculture to built-up areas. Regarding the increasing population growth and urbanisation in the region, the outcomes of this study can help make informed decisions for the management and protection of natural resources in the study area.
\end{abstract}

Key words: landscape dynamics, satellite imagery, Cellular Automata-Markov Chain, Intensity Analysis, Iran.

\footnotetext{
* Mohammad HASANI, Abdolrassoul SALMANMAHINY, Alireza Mikaeili TABRIZI, Gorgan University of Agricultural Sciences and Natural Resources, College of the Environmental Sciences, Basij square, Gorgan, Golestan Provice, Iran, e-mails: hasani.mohammad64@yahoo.com, rassoulmahiny@gmail.com, amikaeili@gau.ac.ir, ORCIDs: https://orcid.org/0000-0002-8731-1666, https://orcid.org/0000-0002-5188-7356
} 


\section{INTRODUCTION}

The concept of land use/land cover (LULC) change indicates the conversion of land utilities and resources (Prakasam, 2010). Change detection analyses are important for studying the linkage between human activities and the changes in the environment (Srivastava et al., 2012). In this context, accessibility to real-time data and updated information on the process of change are key factors for planning, decision making and management. The LULC change process occurs on a large scale and, therefore, we need new technologies in environmental studies to have a detailed, accurate, fast and economical estimation of such changes. Currently, remote sensing (RS) is an efficient technology to access a portion of such data which can also be forecasting and multi-temporal. With a substantial progress in RS and Geographical Information System (GIS) technologies, LULC change mapping is considered a useful methodology for improving land allocation studies for different land categories such as agricultural activities, urbanisation, and industrialisation (Selcuk et al., 2003).

Digital change detection methods applying multi-temporal satellite imagery can assist the interpretation and assessment of landscape dynamics and provide basic data for modelling LULC change processes in GIS environments. Over the recent decades, LULC change studies have played a major role in spatial studies and environmental change investigations (Liu and Deng, 2010) and produced important information for studying and analysing the processes of LULC patterns.

The analysis of the dynamics of LULC arrangements improves our understanding of landscape evolution during a particular period (Warwade et al., 2013). RS has been increasingly applied in updating LULC maps (Lo and Choi, 2004). Landsat images (e.g. TM sensor) have offered valuable and unique observations of the earth's surface over the recent decades (USGS, 2014). Additionally, Landsat images are now freely available to the scientific community and the general public, which means we can obtain plenty of information for land use monitoring and the evaluation of landscape dynamics (Chander et al., 2009; El Bastawesy, 2014).

There are several methods available for monitoring and detecting LULC changes using RS data, yet there is no universal consensus on which model or algorithm is the best in all circumstances (Srivastava et al., 2012). In this case, post-classification change detection methods are known as useful and fast methods that compare bi-temporal images collected by satellites at different times (Abd El-Kawy et al., 2011). The post-classification comparison can supply complete from-to change information but the classification stage of the algorithm is very time-consuming because the accuracy of the classification is very important to achieve an acceptable change detection result (Liu et al., 2004). We used the post-classification change detection method to detect LULC conversions on Landsat imagery.

A wide range of techniques is available to predict LULC changes, each having its own strengths and limitations (Overmars et al., 2003; Verburg and Veld- 
kamp, 2005). These techniques include Logistic Regression approaches, Neural Networks, Cellular Automata, Markov chains, Micro-economic, and Multi-agent simulations (Verburg and Veldkamp, 2005). In this regard, Markov chain analysis is a random modelling method that has been frequently applied in the analysis of LULC dynamics at different scales (Muller and Middleton, 1994). Cellular Automata model is a well suited technique for exploring urban growth dynamics (Verburg et al., 2006). Therefore, for modelling future LULC changes, the Cellular Automata-Markov Chain (CA-MC) technique was implemented in this study.

RS and Markov analysis have been applied to predict and model LULC change in many studies over different study areas. For instance, Yuan et al. (2005) extended a method for mapping and monitoring LULC changes applying multi-temporal Landsat imagery in the Minnesota metropolitan area in the years 1986 to 2002 . Their findings indicated that urban land increased, while in rural areas land use types like forest, agriculture and wetland reduced. Bhagawat (2011) used GIS information to extract land use changes based on statistical analysis of four LULC maps of the Kathmandu Metropolitan area. Gong et al. (2015) studied the LULC pattern for the city of Harbin, China. They applied RS, GIS, and CA-MC model to investigate land dynamics between 1989 and 2007. Their results showed that the built-up area increased, while croplands decreased. Halmy et al. (2015) studied LULC changes between three dates (1988, 1999, and 2011) in the north-western desert of Egypt using CA-MC integrated approach to simulate future changes. The CA-MC model was applied to simulate LULC changes up to 2023 based on the current trends. Their analysis revealed that an important built-up growth happened in the croplands westward and northward of the landscape, and expansion in quarries, and development in residential centres also occurred in their study area.

The main objectives of the current study are to: 1) provide a map of LULC changes in the study area between 1992 and 2011;2) apply the CA-MC model to predict potential changes by 2030 based on the existing trends; and 3) employ intensity analysis to calculate the integrity of size and stationarity of land use changes.

\section{THE MATERIALS AND METHODS}

\subsection{The study area}

The area of interest spans the Gorgan Township in the Golestan Province, in north-eastern Iran (Fig. 1). The city is the capital of the Golestan Province which is limited to $54^{\circ} 10^{\prime}-54^{\circ} 45^{\prime} \mathrm{E}$ and $36^{\circ} 44^{\prime}-36^{\circ} 58^{\prime} \mathrm{N}$, with a surface area of around 81.16 sq. km. The Caspian Sea and Hyrcanian forests in the northwest 
and south of the study area are the main environmental characteristics of this region. The main land uses and land covers are agriculture and forest (Sakieh et al., 2015). The population has increased rapidly in recent years because of high growth rate and immigration in the area (Salmanmahiny, 2013). The growth in the population caused considerable changes in LULC in the study area, and therefore, LULC analysis for sustainable land use has become increasingly important for the government of this region.



Fig. 1. Geographical location of the Gorgan Township in the Golestan Province, north-eastern Iran Source: own work based on Landsat satellite imagery.

\subsection{Database and Image pre-processing}

Landsat TM 5 images with a spatial resolution of 30 m of August 1992 and August 2011 were employed for image classification and LULC categorisation. These images were downloaded from the USGS database (http://earthexplorer.usgs.gov/). The image classification process was conducted in the IDRISI Selva software. For supervised classification of temporal RS data, atmospheric correction step could be relatively safely ignored since separate classification processes can minimise the effect of atmospheric errors (Song et al., 2001). To improve visual interpretation, the ENVI software (v4.4) and the linear contrast 
expansion was used (Linear 2\%). Then the bands of Landsat 5 were used to prepare spectral bands except for the thermal band (band 6) and the images were cropped for the study area.

\subsection{Classification of images}

The pre-processed satellite images were categorised applying the supervised maximum likelihood algorithm (MLC) in the IDRISI Selva software. MLC algorithm is one of the most common supervised classification methods utilised for RS images. This procedure is based on the foundation of the probability analysis that a pixel belongs to a specific class (Rawat and Kumar, 2015). The fundamental theory supposes that these probabilities are equivalent for all classes and all input bands have uniform distributions. Among other supervised classification methods, MLC is time-consuming and strongly dependent on the normal distribution of data in entire input bands, and inclined to over-classify signatures with comparatively large values in the covariance matrix; however, the method can also be accurate for LULC classification if training samples were selected correctly (Paliwal and Katiyar, 2015). This classification analyses probability for each cell belonging to a specific land use and allocates a cell to a land use with the highest probability of membership (Rawat and Kumar, 2015).

The Kappa coefficient and error matrix methods were employed to evaluate the mapping accuracy. Five LULC categories including built-up area, forest, agricultural land, remnant vegetation, and water bodies were recognised in the study area. To remove the 'salt and pepper' effect, a mode filter was applied to the resultant classified images (Nahuelhual et al., 2012).

\subsection{LULC change detection and analysis}

Change detection analyses illustrate changes between images in the same landscape during time intervals. The classified images of different times can detect and reveal temporal LULC changes of a landscape. This analysis is useful to understand changes happening in different classes of LULC such as an increase of urban areas or a decrease in agricultural land (Hegazy and Kaloop, 2015). Post-classification comparison was used to detect and assess LULC changes. A pixel-based comparison was employed in order to produce change information on a pixel basis and make the interpretation of the changes more efficient (fromto change information). The temporal classified images were compared utilising cross-tabulation to distinguish qualitative and quantitative changes between 1992 and 2011. A change matrix (Weng, 2001) was produced in the IDRISI Selva software. Consequently, quantitative information was compiled regarding area extents of different LULC categories and their temporal changes including gains and losses between 1992 and 2011. 


\subsection{LULC change prediction}

There are several methods and analytic tools to predict LULC changes (Overmars et al., 2003). The CA-MC is a projection model which illustrates the probabilistic alterations of a distinct category from one state to another. When applied to LULC layers, the CA-MC often specifies both time and a limiting set of states as distinct values. Transformations between the states of a system are registered through a transition matrix which shows probability of altering from one state to another (Clark, 1965). The CA-MC is a statistics modelling approach that has been frequently employed to analyse the dynamics of the LULC change process at various scales (Muller and Middleton, 1994). Furthermore, The CA-MC model is a powerful technique for predicting a LULC change and was implemented in different studies (Guan et al., 2011; Kamusoko et al., 2009). Further, it can forecast two-way transitions among LULC classes (Pontius and Malanson, 2005). The prediction of future LULC change utilising the CA-MC model can be accomplished in three steps, i.e. by: 1) using the MC analysis between 1992 and 2011 LULC maps to compute transition matrices; 2) computing LULC transition potential maps; and 3) applying the CA model to the transition data (matrices and potential maps) to forecast the spatial distribution of LULC. We used the statistical data of the population to estimate the required area for urban expansion. The population was 418,775 and its growth rate was 1.9 in the year 2011.

\subsection{Intensity analysis}

The size of an LULC change can be derived from the traditional transition matrix; although to achieve a deeper understanding of the LUC, it is necessary to connect the patterns of changes to processes (Zaehringer et al., 2015). An intensity analysis is a set of relevant methods that facilitates a deeper evaluation of a changing process at multiple levels. This method is an accountancy framework to explain the mechanism of a definite variable within time profiles and to quantify the degree to which LULC changes are non-uniform at different levels of detail (Aldwaik and Pontius, 2012; Enaruvbe and Pontius, 2015). In addition, an intensity analysis (Pontius et al., 2004, 2013; Aldwaik and Pontius, 2012, 2013; Teixeira et al., 2016) substantiates a quantitative framework with a deep analysis of an LULC change, to the former LULC change detection procedure, in connection with either a spatial extension or configuration-based attributes of a landscape (Hasani et al., 2017). An intensity analysis provides an additional level of knowledge since it measures whether a supervised transformation from one category to another diverges from an evidently uniform process (Aldwaik and Pontius, 2012, 2013). Here we present the technical details of an intensity 
analysis at three levels of interval, category, and transition. The interval level evaluates how the size and rate of an LULC conversion differs across time profiles. For the corresponding time span, the category level analyses how the measure and intensity of gross gains and losses in each land feature alters across LULC categories. For a specific LULC category, the transition level surveys how the intensity and size of a category's transitions change across the other categories which are available for that transition (Aldwaik and Pontius, 2012, 2013). The uniform change hypothesis value is distinctly quantified for each of these hierarchical levels. In this procedure the uniform change hypothesis is individually quantified for each level.

At each level, the intensity technique searches for stationary patterns across time intervals (Zhou et al., 2014). The interval level analyses the stationarity of landscape patterns and provides a degree of the similarity of pattern changes in different time intervals. The analysis computes the intensity of an annual change in various time intervals and then compares each interval's intensity to a uniform intensity rate of change. The category level analysis gives the intensity of annual gross gains and losses for each category. The stationarity for the annual gross gains and losses means that the intensity of a category's gain or loss is either larger or smaller than the uniform line for all time intervals (Zhou et al., 2014). Therefore, that category is assumed stationary in terms of gains or losses. The transition level calculates the given transition intensity from say category $\boldsymbol{m}$ to category $\boldsymbol{n}$. For the transition level of the gains or losses, stationary means that the gain of category $\boldsymbol{n}$ either targets or avoids category $\boldsymbol{m}$ for all time intervals, or the loss of category $\boldsymbol{m}$ either targets or avoids category $\boldsymbol{n}$ for all time intervals, so the transition from $\boldsymbol{m}$ to $\boldsymbol{n}$ is stationary, considering the gain of category $\boldsymbol{n}$ or the loss of category $\boldsymbol{m}$ (Zhou et al., 2014; Pontius et al., 2013).

\section{THE RESULTS}

\subsection{LULC cover images}

The classified images achieved from pre-processing and supervised classification are illustrated in Fig. 2 that shows the magnitude of change for different LULC categories. These maps show the LULC patterns of the study area. To assess the accuracy of classification, the LULC maps were compared to the reference data created using a collection of 100 sample points (with random distribution) on Google Earth. The results of accuracy assessment indicated the overall accuracies of $96 \%$ for 1992 and $91 \%$ for 2011 . The Kappa coefficients for 1992 and 2011 maps were 0.81 (Table 1). A short description of these results is presented below. 
Table 1. Landsat imagery classification accuracy

\begin{tabular}{|l|c|c|}
\hline \multicolumn{1}{|c|}{ Variable } & Land Use 1992 & Land Use Tm 2011 \\
\hline Kappa Index & 0.81 & 0.81 \\
\hline Total Accuracy (\%) & 96 & 91 \\
\hline
\end{tabular}

Source: own work

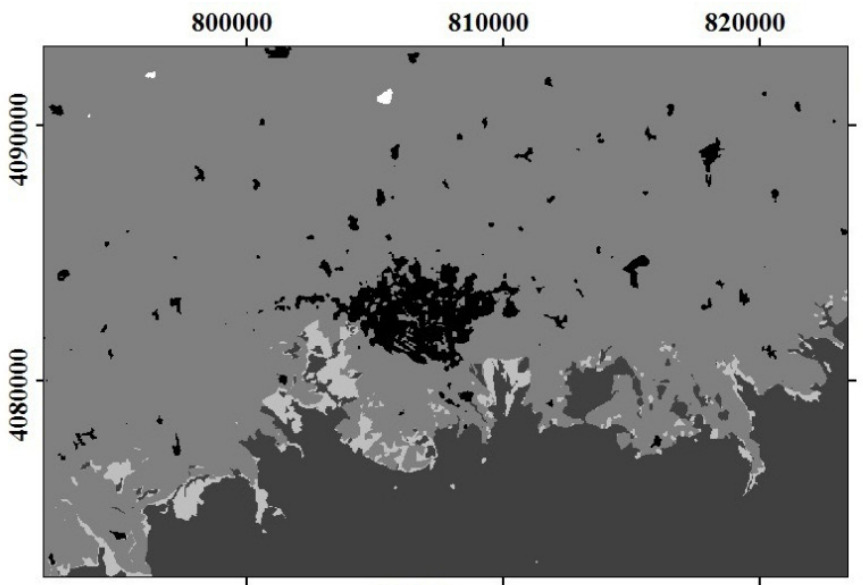

$\begin{array}{lllll}0 & 1 & 2 & 4 & 6\end{array}$

a. 1992

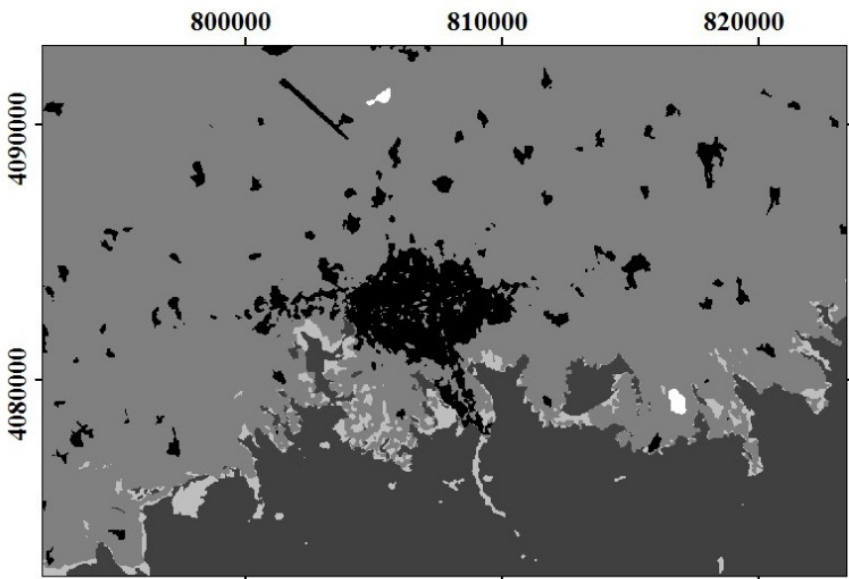

Built Area

Forest

Agriculture

Remnant Vegetation

Water Body

\section{b.2011}

Fig. 2. Temporal LULC layers of Gorgan Township

Source: own work. 


\subsection{Change detection analysis}

Fig. $2 \mathrm{a}$ and Fig. $2 \mathrm{~b}$ portray the LULC spatial distributional pattern of the Gorgan Township area for the years 1992 and 2011, respectively. The main factors of land changes were recognised in the study area and completed using the available technical reports. The principal type of human-caused land alteration was urbanisation (Salmanmahiny, 2013). The LULC variables were calculated to assess land changes by applying multi-date satellite images for the period 1992-2011 (Tables 2, 3 and Fig. 3). These data sets reveal that in 1992 the built-up area covered $3.25 \%$ ( 23,864 cells), forests covered $24.70 \%$ ( 181,308 cells), agriculture covered $69.34 \%$ (508,938 cells), remnant vegetation covered $2.66 \%$ (19,474 cells) and water bodies covered $0.05 \%$ (366 cells). Up to 2011, the built-up area rose to $5.58 \%$ (40,983 cells), forest increased slightly and reached $24.97 \%$ (183,269 cells), agriculture shrank to $66.91 \%$ (491,065 cells), remnant vegetation decreased to $2.42 \%$ (17,762 cells) and water bodies changed to $0.12 \%$ (871 cells) (Table 3$)$.

Table 2. Change detection matrix of the Gorgan Township in 1992-2011

\begin{tabular}{|c|c|c|c|c|c|c|}
\hline \multirow{2}{*}{\multicolumn{2}{|c|}{ Year / LULC categories }} & \multicolumn{5}{|c|}{2011} \\
\hline & & \multirow{2}{*}{$\begin{array}{c}\begin{array}{c}\text { Built-up } \\
\text { area }\end{array} \\
21,744\end{array}$} & \multirow{2}{*}{$\begin{array}{c}\text { Forest } \\
0\end{array}$} & \multirow{2}{*}{$\begin{array}{c}\text { Agriculture } \\
0\end{array}$} & \multirow{2}{*}{$\begin{array}{c}\begin{array}{r}\text { Remnant } \\
\text { vegetation }\end{array} \\
0\end{array}$} & \multirow{2}{*}{$\begin{array}{c}\begin{array}{c}\text { Water } \\
\text { body }\end{array} \\
0\end{array}$} \\
\hline \multirow{5}{*}{1992} & Built-up area & & & & & \\
\hline & Forest & 47 & 174,328 & 2,581 & 4,025 & 327 \\
\hline & Agriculture & 19,122 & 3,043 & 478,568 & 7,907 & 298 \\
\hline & Remnant vegetation & 70 & 5,898 & 7,676 & 5,830 & 0 \\
\hline & Water body & 0 & 0 & 120 & 0 & 246 \\
\hline
\end{tabular}

Source: own work.

Table 3. Area of change in different LULC categories in the Gorgan Township in 1992-2011

\begin{tabular}{|l|c|c|c|c|c|c|}
\hline \multirow{2}{*}{ LULC categories } & \multicolumn{2}{|c|}{1992} & \multicolumn{2}{c|}{$\mathbf{2 0 1 1}$} & \multicolumn{2}{c|}{ Change rate 1992-2011 } \\
\cline { 2 - 7 } & cell & $\mathbf{\%}$ & cell & \% & cell & \% \\
\hline Built-up area & 23,864 & 3.25 & 40,983 & 5.58 & $+17,119$ & +2.33 \\
\hline Forest & 181,308 & 24.70 & 183,269 & 24.97 & $+1,961$ & +0.27 \\
\hline Agriculture & 508,938 & 69.34 & 491,065 & 66.91 & $-17,873$ & -2.43 \\
\hline Remnant vegetation & 19,474 & 2.66 & 17,762 & 2.42 & $-1,712$ & -0.24 \\
\hline Water body & 366 & 0.05 & 871 & 0.12 & +505 & +0.07 \\
\hline Total & 733,950 & 100 & 733,950 & 100 & 0 & 0 \\
\hline
\end{tabular}

Source: own work. 


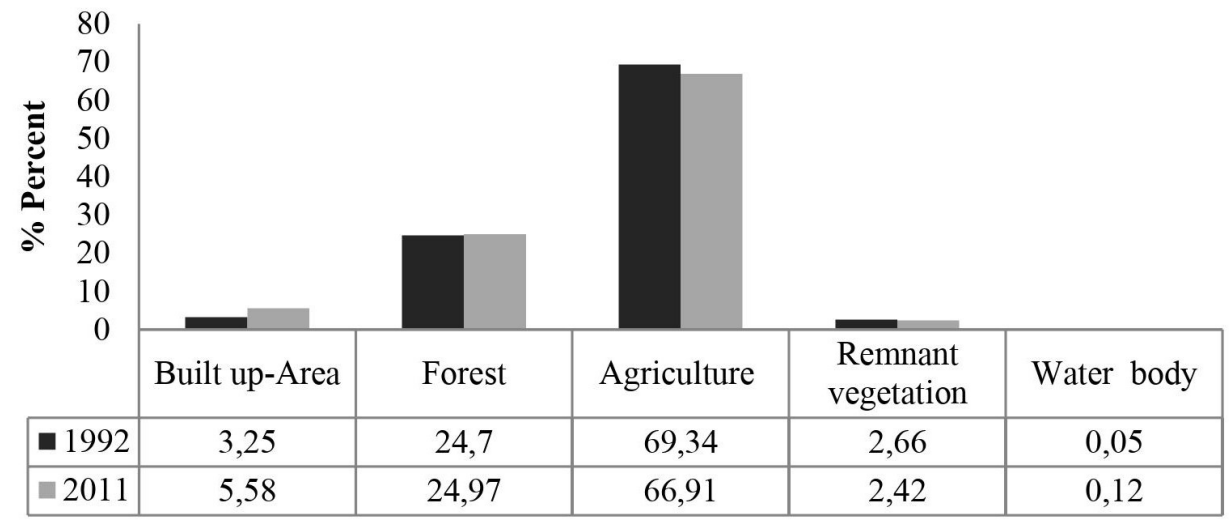

Fig. 3. Illustration of LULC changes in percent (1992-2011) in the Gorgan Township Source: own work.

\subsection{CA-MC model results}

An examination of the transition probabilities in Table 4 indicates an increase in the built-up area and a decrease in agriculture during the studied intervals. In each of the study intervals, each LULC category experienced increases in some localities and decreases in others (Table 5). The land cover maps of the years 1992 and 2011 were used to predict the 2030 LULC layer. Future LULC changes and statistics are given in Fig. 4 and Table 5.

Table 4. Transitional probability matrix derived from the land use/land cover map in the Gorgan Township in 2011-2030

\begin{tabular}{|c|c|c|c|c|c|c|}
\hline \multirow{2}{*}{\multicolumn{2}{|c|}{ Year / LULC categories }} & \multicolumn{5}{|c|}{2030} \\
\hline & & \multirow{2}{*}{$\begin{array}{c}\begin{array}{c}\text { Built-up } \\
\text { area }\end{array} \\
29,693\end{array}$} & \multirow{2}{*}{$\begin{array}{c}\text { Forest } \\
0\end{array}$} & \multirow{2}{*}{$\begin{array}{c}\text { Agriculture } \\
0\end{array}$} & \multirow{2}{*}{$\begin{array}{c}\begin{array}{r}\text { Remnant } \\
\text { vegetation }\end{array} \\
0\end{array}$} & \multirow{2}{*}{$\begin{array}{c}\begin{array}{c}\text { Water } \\
\text { body }\end{array} \\
0\end{array}$} \\
\hline \multirow{5}{*}{2011} & Built-up area & & & & & \\
\hline & Forest & 251 & 14,0525 & 14,042 & 26,386 & 0 \\
\hline & Agriculture & 18,448 & 0 & 367,601 & 0 & 0 \\
\hline & Remnant vegetation & 35 & 510 & 8,492 & 2,725 & 0 \\
\hline & Water body & 0 & 0 & 0 & 0 & 444 \\
\hline
\end{tabular}

Source: own work. 
Table 5. Land use statistics of the Gorgan Township during 2011-2030 time profile

\begin{tabular}{|l|c|c|c|c|c|c|}
\hline \multirow{2}{*}{ LULC categories } & \multicolumn{2}{|c|}{2011} & \multicolumn{2}{c|}{2030} & \multicolumn{2}{c|}{ Change rate 2011-2030 } \\
\cline { 2 - 7 } & cell & $\mathbf{\%}$ & cell & \% & cell & \% \\
\hline Built-up area & 40,983 & 5.58 & 58,994 & 8.03 & $+18,011$ & 2.45 \\
\hline Forest & 183,269 & 24.97 & 183,285 & 24.97 & +16 & 0 \\
\hline Agriculture & 491,065 & 66.91 & 473,585 & 64.52 & $-17,480$ & -2.39 \\
\hline Remnant vegetation & 17,762 & 2.42 & 17,241 & 2.37 & -521 & -0.05 \\
\hline Water body & 871 & 0.12 & 845 & 0.11 & -26 & -0.01 \\
\hline Total & 733,950 & 100 & 733,950 & 100 & 0 & 0 \\
\hline
\end{tabular}

Source: own work.

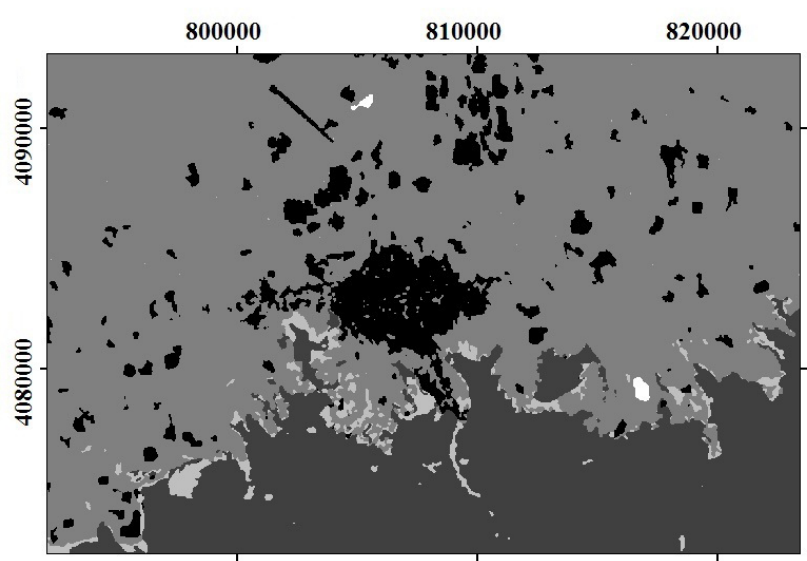

2030

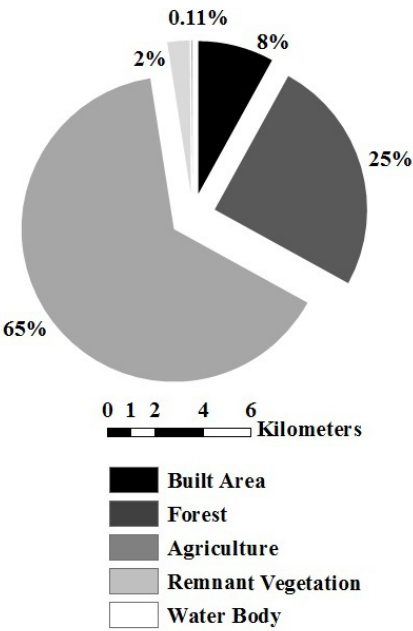

Water Body

Fig. 4. Temporal and predicted LULC layers for the Gorgan Township in 2030

Source: own work.

\subsection{Results of the intensity analysis}

The interval level intensity analysis produced Fig. 5 in which bars to the left of the graph display the change areas and those to the right indicate change intensity of time intervals. The left side of Fig. 5 reveals that the speed of change in the first time interval was larger than that of the second time interval. Based on Fig. 5, the uniform change intensity was calculated to be $0.26 \%$ of the study area. With 
regard to the uniform intensity line, if an interval's bar passes beyond the uniform line, it indicates the change is comparatively fast for that time interval, otherwise, the change is comparatively slow for that time interval. In this regard, change intensity seems to be slowed through the second time interval in which the intensity of the LULC conversions did not exceed the uniform line.

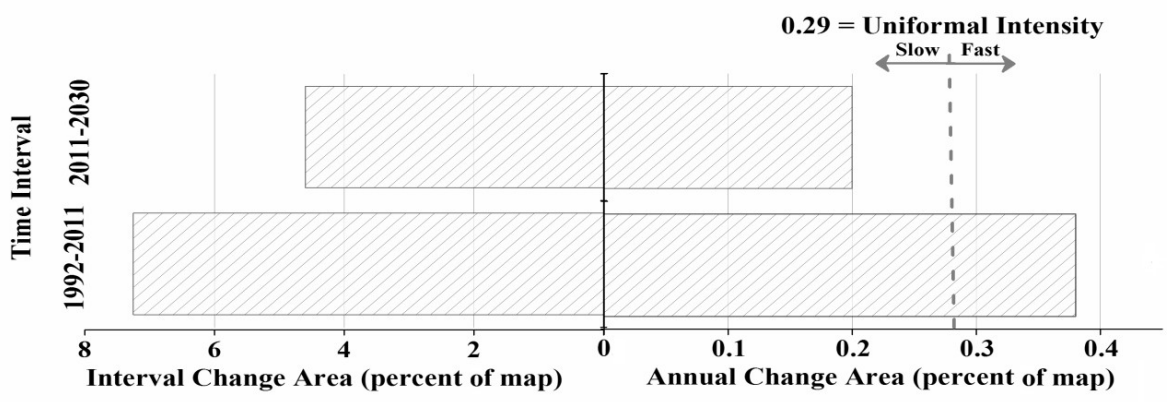

Fig. 5. Time intensity analysis for the periods 1992-2011 and 2011-2030. The hypothetical uniform change intensity at the time interval level is indicated by the dashed vertical line

Source: own work.

The results of the intensity analysis at the category level are shown in Fig. 6 . In this figure, each category has a pair of bars that indicates gross gain and gross loss of the corresponding category. The dashed vertical lines display the value of uniform annual change intensity across the study area. If a bar expands beyond the dash uniform line, the change is comparatively active for that category; otherwise, the change is comparatively dormant for that category. Bars on the lefthand side of the graph show gross annual area of losses and gains, while those on the right display the intensity of annual gains and losses for each category in the study area. Based on Fig. 6, the value of the uniform change intensity was computed to be $0.38 \%$ (1992-2011) and $0.15 \%$ (2011-2030) in both time intervals. Such values indicate that the dynamics of the landscape at an LULC category tended to be more intense through the first time interval. Fig. 6 shows that the built-up area has the largest size regarding annual gains during both intervals. Agriculture has the largest size in terms of the annual losses during both time intervals. Forest gains and losses were dormant for both time intervals while the gains and losses of remnant vegetation were active during these times. The right side of Fig. 6 demonstrates that the bars for loss of remnant vegetation and water bodies expand beyond the dash uniform line in both time intervals, indicating that the remnant vegetation sustained losses more intensively in the landscape compared to other categories. 


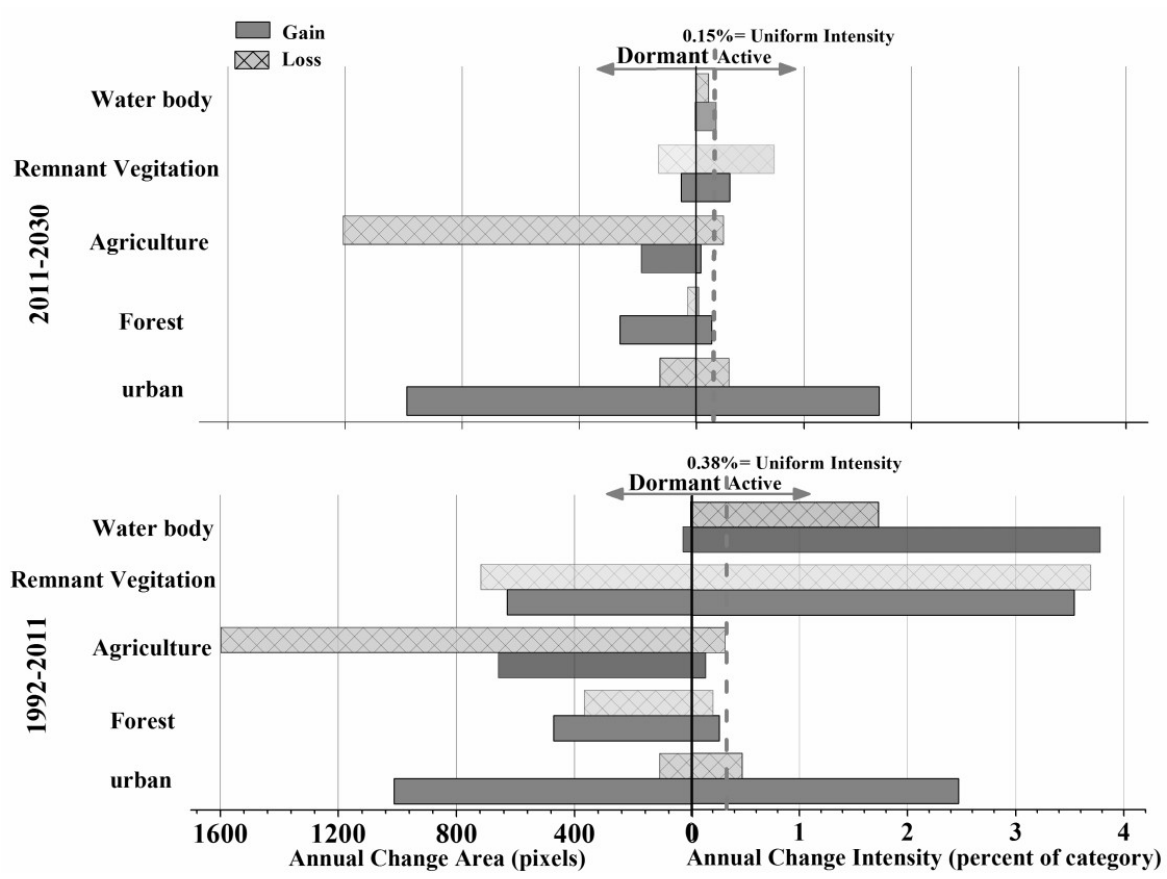

Fig. 6. Category intensity analysis for gross gain and gross loss at the category level for the periods 1992-2011 and 2011-2030

Source: own work.

Fig. 7 illustrates the results at the transition level for the LULC categories. Fig. 7 highlights that the intensity change has slowed through the second time interval at the transition level of the LULC conversions in general. The left side of the graph displays gross annual area of transitions, while the right side of the graph displays the intensity of annual transitions. Fig. 7a illustrates results of the transition level intensity analysis in relation to transitions from water bodies, remnant vegetation, agriculture and forest to built-up area. Fig. 7a reveals that the built-up area gains target agriculture and avoids other categories in the two time intervals. Thus, the transition from agriculture to built-up area is stationary, regarding the gain of the built-up area. Fig. $7 \mathrm{~b}$ represents the interactivity between the agriculture category and other land features, and shows the annual rate and the transition intensity from other categories to agriculture use. Fig. $7 \mathrm{~b}$ reveals that agriculture gains target remnant vegetation and water bodies and avoids forest category for both time intervals. Thus, the transition from forest, remnant vegetation and water bodies to agriculture is stationary, regarding the gain of the agriculture category. This exists when agriculture gains, it tends to gain intensively from both 
remnant vegetation and water bodies more than from other categories. Based on these results, a series of important systematic transitions in the study area can be identified. In this regard, there are systematic transitions from remnant vegetation to the agriculture category and from agriculture to built-up area.

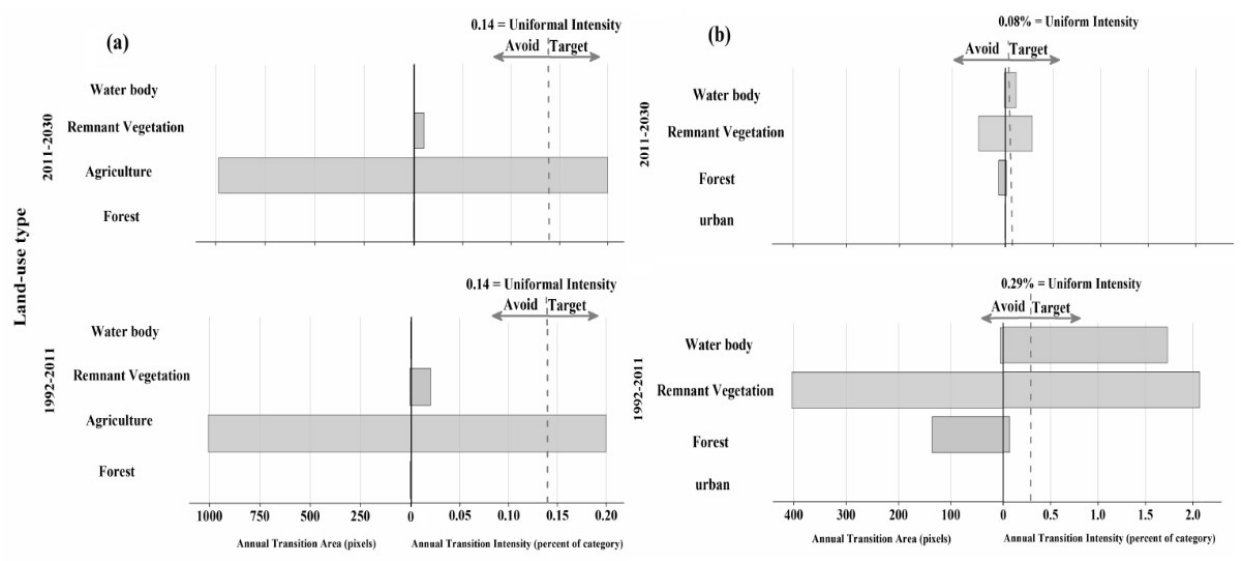

Fig. 7. Transition intensity analysis for two time intervals: 1992-2011 and 2011-2030

Source: own work

\section{DISCUSSION}

In this paper multiple methods were used to illustrate the dynamics of the study area in terms of LULC features, changing intensities, and predictive CA-MC model. The main findings of the present study are described in the following paragraphs.

Fig. 2 and 4 display how the overall change is accelerating in the two time intervals. Population growth is the major cause of the LULC change process in the area (Halmy et al., 2015, Rawat and Kumar, 2015). A population increase is one of the important issues that exert heavy pressure on land resources by accelerating and intensifying the LULC change process (Nitsch et al., 2012; Sakieh et al., 2015). The data recorded in Table 3 and Fig. 3 indicates that significant changes (increase and decrease) happened in the LULC pattern of the Gorgan Township in the first time interval (1992-2011). Within the initial time interval, the built-up area increased from 23,864 cells in 1992 to 40,983 cells in 2011 , which accounts for a $2.33 \%$ change of the total study area. Because of the forestry projects in nearby cities, forests increased from 181,308 cells in 1992 
to 18,3269 cells in 2011 , which accounts for a $+0.27 \%$ change. The agriculture decreased from 508,938 cells in 1992 to 491,065 cells in 2011, which accounts for a $-2.43 \%$ change. The remnant vegetation decreased from 19,474 cells in 1992 to 17,762 cells in 2011 which accounts for a $-0.24 \%$ change. The water bodies developed from 366 cells in 1992 to 871 cells in 2011, which accounts for a $+0.07 \%$ change. In the same manner, Table 5 illustrates the LULC change pattern of the Gorgan Township in the second time interval (2011-2030). In this time interval, the built-up area increased by $2.45 \%$ of the total study area. Regarding conservation policies implemented in this region, the forest area has not changed during this time interval. The agriculture category decreased accounting for $-2.39 \%$. The remnant vegetation and water bodies decreased accounting for $-0.05 \%$ and $-0.01 \%$, respectively.

To understand the LULC changes in the different categories during the second time interval, a change detection matrix (Table 4) was prepared, which exhibits that:

I. 251 cells of the forest cover changed into built-up areas, 14,042 cells to agriculture and 26,386 cells to remnant vegetation;

II. 18,448 cells of agriculture transformed into built-up area; and

III. 35 cells of remnant vegetation changed into built up-area, 510 cells in forest and 8,492 cells converted into agriculture.

In our study, the built-up area category is one of the most dynamic land features and the gaining intensities of this land feature are actively targeting the loss of agriculture, forest and remnant vegetation. Urban growth is affecting multiple categories in the study area. Agriculture is most impacted by such a process (Fig. 7a). There are also heavy systematic transitions from agriculture to the built-up area category. This pattern of urban growth is also associated with reduced exposure to natural hazards and decreased values for tourism suitability (Hasani et al., 2017).

Agriculture is another dynamic land feature and the gaining or losing intensities of this land feature are actively targeting the loss of remnant vegetation, forest and water bodies (Fig. 7b). Fig. 7b displays the results for the transitions from other categories to agriculture. It reveals that the largest transition is from remnant vegetation, then forest and also a small transition from water bodies. In particular, this exists when agriculture gains, it tends to gain intensively from both remnant vegetation and forest (more than other categories). In addition, remnant vegetation is mostly interactive with forest category and there are systematic transitions from forest ecosystems into this land feature (Sakieh et al., 2016).

Our study indicated that the LULC change intensities in the second time interval decelerated compared to the initial time interval. Furthermore, the results showed that by the year 2030, residential and urban centres may consume farmlands in the northern part of the study area. 


\section{CONCLUSIONS}

In this research we obtained LULC maps using Landsat TM images of the years 1992 and 2011 and used them to survey the LULC change pattern in the Gorgan Township. The intensity analysis helped us provide deeper insight into the land units discovered in the LULC studies. The intensity analysis approach not only enabled us to study the nature of the LULC classes, but it also supplied valuable information about land-use dynamics.

This study mainly highlighted the mechanism of urban growth in the study area, which is occurring at the cost of the consumption of ecologically valuable land resources. Between 1992 to 2011 urbanisation increased to about $2.33 \%$ due to a rapid population growth. Our prediction showed that by 2030 the future urban area may increase up to $2.45 \%$. Our findings also indicated a heavy systematic transition from agriculture to built-up areas. The results clearly indicate an alarming direct relationship between urbanisation and agricultural land decrease, which is also common elsewhere in the Golestan Province. This increased urban growth may have various impacts on infrastructure, land use, natural resources, and the economy of the Gorgan Township. With regards to population growth and urbanisation, the outcomes of this study can provide important information for informed decision making and the protection of natural resources in this area.

\section{REFERENCES}

ABD EL-KAWY, O.R., RØD, J.K., ISMAIL, H.A. and SULIMAN, A.S., (2011) 'Land use and land cover change detection in the western Nile delta of Egypt using remote sensing data', Appl Geogr, 31, pp. 483-494. https://doi.org/10.1016/j.apgeog.2010.10.012

ALDWAIK, S.Z. and PONTIUS, R.G.Jr., (2012), 'Intensity analysis to unify measurements of size and stationarity of land changes by interval, category, and transition', Landscape and Urban Planning, 106, pp. 103-114. https://doi.org/10.1016/j.landurbplan.2012.02.010

ALDWAIK, S.Z. and PONTIUS, R.G.Jr. (2013), 'Map errors that could account for deviations from a uniform intensity of land change', International Journal of Geographical Information Science, 27 (9), pp. 1717-1379. https://doi.org/10.1080/13658816.2013.787618

BHAGAWAT, R. (2011), 'Application of remote sensing and GIS, land use/land cover change in Kathmandu metropolitan city', Nepal J. Theor. Appl. Inform. Technol, 23 (2), pp. 80-86.

CHANDER, G., MARKHAM, B.L. and HELDER, D.L. (2009), 'Summary of current radiometric calibration coefficients for Landsat MSS, TM, ETM+, and EO-1 ALI sensors', Rem. Sen. Envi, 113 (5), pp. 893-903. https://doi.org/10.1016/j.rse.2009.01.007

CLARK, W. (1965), 'Markov chain analysis in geography: an application to the movement of rental housing areas', Ann. Assoc. Am. Geogr., 55 (2), pp. 351-359. https://doi.org/10.1111/j.1467-8306.1965.tb00523.x

EL BASTAWESY, M. (2014), 'Hydrological Scenarios of the Renaissance Dam in Ethiopia and Its Hydro-Environmental Impact on the Nile Downstream', J. Hydro. Engin., http://dx.doi. org/10.1061/ (ASCE)HE.1943-5584.0001112. 
ENARUVBE, G. and PONTIUS, R.G.Jr. (2015), 'Influence of classification errors on Intensity Analysis of land changes in southern Nigeria', International Journal of Remote Sensing, 31 (1), pp. 244-261. https://doi.org/10.1080/01431161.2014.994721

GONG, W., YUAN, L., FAN, W. and STOTT, P., (2015), 'Analysis and simulation of land use spatial pattern in Harbin prefecture based on trajectories and cellular automata Markov modelling', International Journal of Applied Earth Observation and Geoinformation, 34 (3), pp. 207-216. https://doi.org/10.1016/j.jag.2014.07.005

GUAN, D., LI, H., INOHAE, T., SU, W., NAGAIE, T. and HOKAO, K. (2011), 'Modeling urban', Ecological Modelling, 222, pp. 3761-3772. https://doi.org/10.1016/j.ecolmodel.2011.09.009

HALMY, M.W.A., GESSLER P.E., HICKE, J.A. and SALEM, B.B. (2015), 'Land use/land cover change detection and prediction in the north-western coastal desert of Egypt using Markov-CA', Applied Geography, 63, pp. 101-112. https://doi.org/10.1016/j.apgeog.2015.06.015

HASANI, M., SAKIEH, Y., DEZHKAM, S., ARDAKANI, T. and SALMANMAHINY, A. (2017), 'Environmental monitoring and assessment of landscape dynamics in southern coast of the Caspian Sea through intensity analysis and imprecise land-use data', Environ Monit Assess. https://doi.org/10.1007/s10661-017-5883-9

HEGAZY, I.R. and KALOOP, M.R. (2015), 'Monitoring urban growth and land use change detection with GIS and remote sensing techniques in Daqahlia governorate Egypt', International Journal of Sustainable Built Environment, 4, pp. 117-124. https://doi.org/10.1016/j.ijsbe.2015.02.005

KAMUSOKO, C., ANIYA, M., ADI, B. and MANJORO, M. (2009), 'Rural sustainability under threat in Zimbabwe - simulation of futurs land use/cover changes in the Bindura district based on the Markov-cellular automata model', Applied Geography, 29, pp. 435-447. https://doi.org/10.1016/j.apgeog.2008.10.002

LIU, J.Y. and DENG, X.Z. (2010), 'Progress of the research methodologies on the temporal and spatial process of LUCC', Chin. Sci. Bull., 55, pp. 1354-1362. https://doi.org/10.1007/s11434009-0733-y

LIU, Y., NISHIYAMA, S. and YANO, T. (2004), 'Analysis of four change detection algorithms in bi-temporal space with a case study', International Journal of Remote Sensing, 25 (11), pp. 2121-2139. https://doi.org/10.1080/01431160310001606647

LO, C.P. and CHOI, J. (2004), 'A hybrid approach to urban land use/cover mapping using Landsat 7 enhanced thematic mapper plus (ETM+) images', Inter. J. Rem. Sen., 25 (14), pp. 26872700. https://doi.org/10.1080/01431160310001618428

MULLER, M.R. and MIDDLETON, J. (1994), 'A Markov model of land-use change dynamics in the Niagara Region, Ontario, Canada', Landscape Ecology, 9, pp. 151-157.

NAHUElHUAL, L., CARMONA, A., LARA, A., ECHEVERRA, C. and GONZJLEZ, M.E. (2012), 'Landcover change to forest plantations: proximate causes and implications for the landscape in south-central Chile', Landscape and Urban Planning, 107 (1), pp. 12-20. https://doi. org/10.1016/j.landurbplan.2012.04.006

NITSCH, H., OSTERBURG, B., ROGGENDORF, W. and LAGGNER, B. (2012), 'Cross compliance and the protection of grassland - illustrative analyses of land use transitions between permanent grassland and arable land in German regions', Land Use Policy, 29, pp. 440-448. https://doi.org/10.1016/j.landusepol.2011.09.001

OTUKEI, J.R. and BLASCHKE, T. (2010), 'Land cover change assessment using decision trees, support vector machines and maximum likelihood classification algorithms', International Journal of Applied Earth Observation and Geoinformation, 12, pp. S27-S31. https://doi. org/10.1016/j.jag.2009.11.002

OVERMARS, K.P., DE KONING, G.H.J. and VELDKAMP, A. (2003), 'Spatial autocorrelation in multi-scale land use models', Ecological Modelling, 164, pp. 257-270. https://doi.org/10.1016/ S0304-3800(03)00070-X 
PALIWAL, M.C. and KATIYAR, S.K. (2015), 'Accuracy Assessment of Land Cover /Land Use Mapping Using Medium Resolution Satellite Imagery', International Journal of Scientific \& Engineering Research, 6 (7), pp. 1428-1432.

PONTIUS, G.R. and MALANSON, J. (2005), 'Comparison of the structure and accuracy of two land change models', International Journal of Geographical Information Science, 19, pp. 243 265. https://doi.org/10.1080/13658810410001713434

PONTIUS JR., R.G, SHUSAS, E. and MCEACHERN, M. (2004), 'Detecting important categorical land changes while accounting for persistence', Agriculture, Ecosystems \& Environment, 101 (2-3), pp. 251-268. https://doi.org/10.1016/j.agee.2003.09.008

PONTIUS JR., R.G., GAO, Y., NICHOLAS, M.G., KOHYAMA, T., OSAKI, M. and HIROSE, K. (2013), 'Design and interpretation of intensity analysis illustrated by land change in Central Kalimantan, Indonesia', Land, 2 (3), pp. 351-369. https://doi.org/10.3390/land2030351

PRAKASAM, C. (2010), 'Land use and land cover change detection through remote sensing approach: A case study of Kodaikanal taluk, Tamil nadu', International Journal of Geomatics and Geosciences, 1 (2), pp. 150-158.

RAWAT, J.S. and KUMAR, M. (2015), 'Monitoring land use/cover change using remote sensing and GIS techniques: A case study of Hawalbagh block, district Almora, Uttarakhand, India', Remote Sensing and Space Sciences, 18, pp. 77-84. https://doi.org/10.1016/j. ejrs.2015.02.002

SAKIEH, Y., SALMANMAHINY, A., JAFARNEZHAD, J., MEHRI, A., KAMYAB, H. and GALDAVI, S. (2015), 'Evaluating the strategy of decentralized urban land-use planning in a developing region', Land Use Policy, 48, pp. 534-551. https://doi.org/10.1016/j.landusepol.2015.07.004

SAKIEH, Y., SALMANMAHINY, A., MIRKARIMI, S.H. and SAEIDI, S. (2016), 'Measuring the relationships between landscape aesthetics suitability and spatial patterns of urbanized lands: An informed modeling framework for developing urban growth scenarios', Geocarto International. https://doi.org/10.1080/10106049.2016.1178817

SALMANMAHINY, A. (2013), Golestan Province Land Use Planning Report, Gorgan University of Agriculture and Natural Resources.

SELCUK, R., NISANCI, R., UZUN, B., YALCIN, A., INAN, H. and YOMRALIOGLU, T. (2003), 'Monitoring land-use changes by GIS and remote sensing techniques: case study of Trabzon', http://www.fig.net/pub/morocco/proceedings/TS18/TS18_6_reis_el_al.pdf 5.

SONG, C., WOODCOCK, C.E., SETO, K.C., LENNEY, M.P. and MACOMBER, S.A. (2001), 'Classification and change detection using Landsat TM data: When and how to correct atmospheric effects?', Remote Sensing of Environment, 75, pp. 230-244. https://doi.org/10.1016/ S0034-4257(00)00169-3

SRIVASTAVA, P.K., HAN, D., RICO-RAMIREZ, M.A., BRAY, M. and ISLAM, T. (2012), 'Selection of classification techniques for land use/land cover change investigation', Advances in Space Research, 50, pp. 1250-1265. https://doi.org/10.1016/j.asr.2012.06.032

TEIXEIRA, Z., MARQUES, J.C. and PONTIUS Jr., R.G. (2016), 'Evidence for deviations from uniform changes in a Portuguese watershed illustrated by CORINE maps: an intensity analysis approach', Ecological Indicators, 66, pp. 382-390. https://doi.org/10.1016/j.ecolind.2016.01.018

VERBURG, P.H. and VELDKAMP, A. (2005), 'Introduction to the Special Issue on Spatial modeling to explore land use dynamics', International Journal of Geographical Information Science, 19 (2), pp. 99-102. https://doi.org/10.1080/13658810410001713362

VERBURG, P.H., KOK, K., PONTIUS, R.G. and VELDKAMP, A., (2006), 'Modeling Land-Use and Land-Cover Change', [in:] LAMBIN E.F. and GEIST H. (eds.) Land-Use and Land-Cover Change, Global Change - The IGBP Series. Springer, Berlin, Heidelberg. https://doi. org/10.1007/3-540-32202-7_5 
WARWADE, P., HARDAHA, M.K., CHANDNIHA, S.K. and KUMAR, D. (2013), 'Land use land cover change detection of Patani micro- watershed of Madhya Pradesh using remote sensing data', Academicjournals, 8 (40), pp. 1983-1990.

WENG, Q. (2001), 'A remote sensing-GIS evaluation of urban expansion and its impact on surface temperature in the Zhujiang Delta, southern China', Inter. J. Rem. Sens., 22 (10), pp. 1999 2014. https://doi.org/10.1080/01431160152043676

YUAN, F., SAWAYA, K.E., LOEFFELHOLZ, B.C. and BAUER, M.E. (2005), 'Land cover classification and change analysis of the twin cities (Minnesota) metropolitan area by multitemporal Landsat remote sensing', Rem. Sens. Envi., 98, pp. 317-328. https://doi. org/10.1016/j.rse.2005.08.006

ZHOU, P., HUANG, J., PONTIUS, R.G. and HONG, H., (2014), 'Land Classification and Change Intensity Analysis in a Coastal Watershed of Southeast China', Sensors, 14, pp. 11640-11658. https://doi.org/10.3390/s140711640 